\title{
NEGOTIATING HISTORY: \\ CROWn APOLOGIES In NEW ZeALAND'S HISTORICAL TREATY \\ OF WAITANGI SETTLEMENTS
}

\author{
MAUREEN HICKEY
}

Public HistoRy ReVIEW, voL 13, 2006, PP108-124

\begin{abstract}
The settlement of the grievances of an indigenous people arising from colonisation is not an easy task. Yet to ignore valid grievances is not only unjust but leaves unreconciled the relationship between the descendants of the settlers and the tangata whenua. Race relations in such a climate will always be fragile. ${ }^{1}$

Rt Hon Sir Douglas Graham Minister in Charge of Treaty of Waitangi Negotiations October 1999
\end{abstract}

\footnotetext{
$\mathrm{O}$ n 25 July 2004 the Prime Minister of New Zealand, Helen Clark, formally delivered an apology on behalf of the Crown to the hapü grouping Te Uri o Hau at a gathering of several hundred people at Otamatea Marae, near Maungaturoto in Northland. The terms of the apology, which had been agreed by the Crown and Te Uri o Hau in their Treaty settlement, included acknowledgement that Crown actions since 1840 had had a pervasive and enduring effect on Te Uri o Hau and had resulted in them losing control over the majority of their ancestral lands. The media reported that Clark and other politicians were 'wooed by marae members into an impromptu dance along the aisle of the marae as the joy and happiness from the hapü at the apology exploded'. Clark told the media that 'the sense of closure that a settlement brings is important to both the Crown and claimants, and delivering the Crown's apology in person marks its significance'. ${ }^{2}$ Te Uri o Hau kaumatua Jim Connelly described the apology as 'the key to our claims. It acknowledges the wrongs committed against our tupuna, who battled for many years for recognition of the wrongs against our people'. ${ }^{3}$ The occasion was further marked by the Crown presenting Te Uri o Hau with totara plaques engraved with the apology in English and Mäori and Te Uri o Hau gifting the Crown a greenstone representing a nearby cemetery, which is possibly the first place that Mäori and Pakeha were laid to rest side by side. ${ }^{4}$
} 
In the late twentieth and early twenty-first centuries apologies became increasingly common on the world stage both as a means of resolving current conflict, but also as part of various movements for reparation or restitution for historical injustices. ${ }^{5}$ Internationally, discussion over whether apologies should be offered and whether some form of reparation is due for historical grievances has spanned war crimes, holocaust restitution, slavery, the treatment of indigenous people in a number of countries including Canada, Australia and the United States, the use of 'comfort women' in various conflicts, apartheid in South Africa and the imposition of poll taxes on Chinese immigrants in a number of countries, amongst others. ${ }^{6}$ These attempts to redress the injustices of the past have drawn academic attention as the mix of legal, political and historical imperatives raise questions about the legitimacy of making judgements on historical events. Since the mid 1990s New Zealand governments have been working through a process of redressing historical grievances of the indigenous Mäori population. This article explores the development and role of Crown apologies in the New Zealand historical Treaty of Waitangi settlements process.

\section{TREATY OF WAITANGI AND BACKGROUND TO GRIEVANCES}

The framework for negotiating and settling the historical grievances of Mäori in New Zealand arises from what is often described as the nation's 'founding document', the Treaty of Waitangi signed by representatives of the British Crown and of Mäori in $1840 .{ }^{7}$ The Treaty was a forward-looking document, drawn up in an attempt to establish a peaceful and mutually beneficial relationship between Mäori and the British Crown at a time of new and changing circumstances.

The Mäori and English texts of the Treaty are not exact translations of each other, but the key features are that 'kawanatanga' (Mäori text) which is translated as governance, or 'sovereignty' (English text) was conveyed to the British Crown. Mäori retained 'rangatiratanga' (or chieftainship) over their resources and taonga (treasures) for as long as they desired, but gave the Crown the right of preemption (the sole right to purchase land from them); and that Mäori were guaranteed all the rights and privileges of British subjects. ${ }^{8}$

The Treaty reflected the Crown's intention to deal with Mäori fairly and honourably, including in land transactions. Those good intentions soon suffered under the practical difficulties of administering a new colony, the demands of settler groups and the complex interaction between two cultures and between the Crown and Mäori. ${ }^{9}$ Over time Crown actions caused grievance to particular iwi and hapü. These included the unfair purchase of land, the failure to reserve lands or to provide promised protections for land, the unjust waging of war, the detention and execution of Mäori without trial in times of war, the confiscation of land, the introduction of land laws which changed the Mäori land tenure system, the taking of sites or resources of cultural and spiritual significance.

Many hapü and iwi protested and sought redress for these grievances from generation to generation, generally through petitions and direct representations to government. Occasionally they used litigation. ${ }^{10}$ For instance, Ngäi Tahu, a South 
Island iwi, date their first claim against the Crown to a breach of contract issue in 1849. They took their first court case against the Crown in 1868 and there were numerous inquiries into their claims in the nineteenth and twentieth centuries. ${ }^{11}$ Iwi from the Waikato, Taranaki and the Bay of Plenty whose land was confiscated in the 1860s petitioned and made representations to Parliament. Te Roroa, of the northern Kaipara, protested about the Crown's failure to fully provide reserves after its purchase of their land in the 1870s for over a century.

In some cases the Crown made attempts to resolve some of the historical grievances; sometimes successfully but often not. At times it responded by setting up special commissions of inquiry, such as the Sim Commission in the 1920 s and the Surplus Land Commission in the 1940s. The terms of reference for such inquiries were often limited and the resulting settlements were later seen to be unfair because they were not usually negotiated with, or ratified by, those who held the grievance. ${ }^{12}$

By the early 1970s a new movement of predominantly urban and welleducated Mäori activists began challenging the failure of successive governments to honour the terms of the Treaty and protesting the on-going loss of Mäori land. There were strong calls for the return of land and other resources. Their sustained and sometimes confrontational protests introduced many Pakeha New Zealanders, who had been taught that the country had a history of enviable race relations, to the Mäori perspective that there were serious grievances to be addressed. In 1975, in the Government set up the Waitangi Tribunal as a permanent commission of inquiry charged with making recommendations on claims brought by Mäori relating to contemporary actions or omissions of the Crown that caused prejudice to Mäori. ${ }^{13}$ Many of the early claims also had historical elements and in 1985 the Tribunal's jurisdiction was extended to claims relating to Crown actions or omissions from $1840 .{ }^{14}$ The Tribunal was to determine the validity of claims and make non-binding recommendations to the Crown on redress for valid claims. The Tribunal has issued over 90 reports on contemporary and historical claims and is currently in hearing or pre-hearing judicial conferencing for historical claims in three districts. ${ }^{15}$

Political and social interest in the Treaty and Mäori grievances grew in the 1980s. A combination of protest, litigation and negotiation saw successive governments accept the need to resolve historical Mäori grievances and improve statutory protection of Mäori land. ${ }^{16}$ In 1990 the National Government was elected on a manifesto which included a pledge to settle the major Treaty claims. ${ }^{17}$ The rationale for this policy was both pragmatic and idealistic: the desire of most New Zealanders to enjoy positive race relation was unlikely to happen if the grievances of the past still blighted the relationship between the Crown and Mäori. ${ }^{18}$ Sir Douglas Graham, the Minister in Charge of Treaty of Waitangi Negotiations, later argued that '[t]he simple fact is that we have to deal with these grievances. Can any country allow sixteen per cent of its population to continue to feel deeply aggrieved about serious injustices? Can we allow its indigenous population to lose all that it holds precious, fail to provide a forum for the 
grievances to be aired for over 150 years, and then say that Mäori are out of time to bring a claim according to the rules of court? This is hardly in keeping with the 'honour of the Crown'.19

The Government formally started negotiations with the Ngäi Tahu and Waikato-Tainui tribes in late 1991 and was considering how to resolve Mäori grievances. ${ }^{20}$ It concluded that the ad hoc attempts of previous governments to settle Mäori claims had been unsuccessful 'because there was little understanding of the totality of the issues' and resolved to try to approach Treaty claims in a 'rational, cohesive and constructive way'. This culminated in the release of detailed Crown proposals for the settlement of Treaty claims for public consultation in 1994, which outlined some key principles to guide future settlements including that to be durable they would they would have to be fair, sustainable and remove the sense of grievance felt by Mäori. ${ }^{21}$

In New Zealand the Crown accepted a responsibility to provide redress to try to address the grievances of Mäori around land loss and the impact of colonisation, before it explicitly considered whether a formal apology to Mäori should form part of that redress. According to Sir Douglas Graham it was the negotiations between Waikato-Tainui and the Crown which taught the Government that reconciliation required something more intangible than monetary or physical redress. He recounted that it was suggested in those negotiations that the Crown should 'formally acknowledge the wrong done and tender a full apology' as only then would it be possible to put the events of the past in 'their proper place - not forgotten but accepted'. ${ }^{22}$ The Crown therefore proposed to explicitly acknowledge historical injustices in future settlements.

Mäori were intensely critical of the Crown settlement proposals and universally rejected them at eleven regional consultation hui (meetings) Ministers attended. ${ }^{23}$ They were angry that the Crown had developed proposals without consulting with them first, that it proposed to cap the total financial redress for the settlement of all claims within a $\$ 1$ billion 'fiscal envelope' and that it wanted to restrict the use of the conservation estate and natural resources as settlement redress. Amidst those issues the Crown's proposal to explicitly acknowledge its historical injustices drew little comment at the consultation hui. ${ }^{24}$

The concept of the Crown offering Mäori an apology was the subject of some of the general public debate around Treaty settlements in the 1990s. Some New Zealanders questioned, and some still do, why the Crown was apologising. Many were unfamiliar with the historical basis for the claims but there were also concerns over whether the current generation was meant to feel guilt for actions of the Crown that they had had no part in and questions about whether focussing on the grievance of the past was either necessary or desirable. There are no published figures to indicate how widespread such views were, but the public consultation process drew submissions that Mäori had benefited from years of European 'civilisation' and did not deserve compensation, that the respondents felt they were being subjected to 'guilt by inheritance' and that the present generation did not bear responsibility for the sins of past generations. ${ }^{25}$ These 
submissions generally asserted that the settlement proposals were based on an erroneous notion that previous generations of non-Mäori New Zealanders had behaved badly when their actions were appropriate in the context of the time and should be assessed according to that time. ${ }^{26}$ To make current and future generations accountable for these alleged wrongdoings would be compounding any injustice.

To some extent the issue for Mäori was whether the injustices of the past could be resolved. As the Minister in Charge of Treaty Negotiations noted, there were challenges for both the Crown and Mäori in moving towards settling Treaty grievances but possibly one of the key issue for Mäori leaders was that '[t]he grievances had been handed down from generation to generation and had become the heritage from those who had gone before. Mäori not only knew the grievance, not only felt it deeply, but also lived it... to lift the burden and remove the grievance left a vacuum that was frightening. Was not it easier to leave the decision to the next generation to worry about? At least that generation would not be able to complain that they had been sold down the river. And for that matter, would any settlement effected with the Crown be acceptable to those ancestors who had suffered under colonial rule? Or was it to be the ultimate fate of every generation to share the grievance with those who had preceded them? ${ }^{27}$

\section{Settlement Process}

Despite the general rejection of the Crown's settlement proposals many tribal leaders acknowledged and welcomed the Crown's resolve to attempt to settle the claims and sought to continue discussions with the Government. The Crown proposals were modified as a result of the consultation process with Mäori and others, and have subsequently provided the broad framework for settlement negotiations. ${ }^{28}$

In addition to a pan-tribal fisheries settlement and settlements reached with Ngäti Whakaue, Ngäti Rangiteaorere and the resolution of claims over Hauai lands prior to 1995, the Crown has since concluded settlements with Ngäti Whakaue, Ngäti Rangiteaorere, Waikato-Tainui, Ngäi Tahu, Ngäti Turangitukua, Pouakani, Te Uri o Hau, Ngäti Ruanui, Ngäti Tama, Ngäti Awa and ancillary claimants, Ngäti Tuwharetoa (Bay of Plenty), Ngaa Rauru Kiitahi, Te Arawa (over their lakes claims), Ngäti Mutunga (Taranaki) and Te Roroa. In addition it has negotiated smaller settlements over Waimakuku, Rotoma and Te Maunga lands. ${ }^{29}$ The Crown is currently in negotiations or pre-negotiation discussions with over twenty other claimant groups. The current government has a target of completing all Treaty settlements by 2020 .

A key element of the settlement process that has developed over the last decade is that claimant representatives have to seek a mandate from their people to negotiate the resolution of their historical claims on their behalf. They then enter into formal negotiations with the Crown and both parties work to develop a settlement package. All major decisions on the Crown's side of the negotiations are made by Cabinet or by relevant Ministers acting under authority delegated by 
Cabinet, but the Office of Treaty Settlements (OTS) is the Crown agency with lead responsibility for negotiations. ${ }^{30}$ The negotiations are confidential between the parties but once the Crown and the iwi negotiators have agreed in principle on a settlement package it is made public. Because of the overlapping nature of the land interests and historical claims of Mäori iwi and hapü the Crown will also consult with other parties who may have interests in the settlement area. The agreement is developed into a Deed of Settlement, which usually runs to well over 100 pages. The negotiators then take the Deed back to their people so that all adult members of the claimant group can vote on whether to accept or reject the Crown's settlement offer. The Crown and the claimant group will explicitly record in the Deed that it settles all of the historical claims of the group. If the agreement is ratified by the people and the Deed is signed, legislation will be passed to give effect to the Deed, including ousting the jurisdiction of the Waitangi Tribunal and the Courts to inquire into the historical claims.

Settlements generally include commercial redress, cultural redress and apology redress. Commercial and cultural redress are intended to address specific effects of, or issues that have arisen out of, historical grievances. The Crown recognises through commercial redress for instance, that generations of Mäori have suffered financial and other losses as a result of Crown breaches of the Treaty. The Crown does not aim to fully compensate claimants financially for their losses. Rather, settlements take into account the fiscal and economic constraints of the country while aiming to be sufficient to redress the claimant group's sense of grievance. The nature and amount of financial and commercial redress the Crown offers in each settlement package largely depends on the severity of the Crown's breaches of the Treaty, the amount of land lost and the size of the current group that holds the grievance. To date settlements have included financial redress totalling $\$ 720$ million, which is usually taken in a mix of cash and Crown assets such as property. ${ }^{31}$

Cultural redress is provided to recognise the claimant group's spiritual, cultural, historical or traditional associations with the natural environment. It aims to address historical grievances about the loss of ownership or guardianship of sites of spiritual and cultural significance, loss of access to traditional foods or resources and the exclusion of the claimant group from decision-making regarding important sites or resources. To date, negotiations on cultural redress have dealt with wähi tapu (sacred places) and other sites of significance, including mountains; rivers and lakes; wetlands, lagoons, indigenous forests and tussock lands; customary freshwater and marine fisheries; geothermal and mineral resources; plant and animal species; moveable taonga (artefacts) and traditional place names. Claimant groups have negotiated cultural redress packages which include the return of land, greater participation in the management of culturally important areas or resources, statutory acknowledgements of their historical, spiritual and traditional associations with an area (aimed at enhancing the group's ability to participate in certain consent processes). Groups have also negotiated protocols with Ministers of the Crown 
setting out how particular government agencies intend to interact with a claimant group on a continuing basis and the restoration of traditional place names. ${ }^{32}$

\section{Apology Redress}

Almost all settlements to date have included some form of Crown apology. The form of the Apology redress has developed over time but generally includes some form of historical account in which the Crown and the claimant group aim to agree text which outlines the history of their interaction, focussing on historical events that have caused grievance. The historical account is followed by a statement of the Crown's acknowledgments of its Treaty breaches and an apology from the Crown to the claimant group. The three parts of the Apology redress interact. The purpose of the historical account is to provide context and explanation for the Crown's acknowledgements of Treaty breach, which in turn forms the basis of the Crown's apology. The Crown's acknowledgments and apology will eventually be recorded in the settlement legislation passed by Parliament, while the historical account (or an abridged form of it) may be included in the legislation as a preamble. The historical account and acknowledgements can, therefore, be extensively negotiated. As Layne Harvey, a member of the Ngäti Awa legal team during their negotiation process, has commented the 'claimants do not want the Crown's view of every claim detail to prevail in the deed and legislation and negotiations over even the smallest word can become terse and hard fought. ${ }^{, 33}$

For the Crown the apology is considered an essential part of the settlement process because it is only through taking explicit responsibility for its past actions, which have breached the Treaty of Waitangi that the Crown can begin to restore its honour. The apology also serves a secondary, but important, function of explaining to the public why the settlement is due. This is necessary both for maintaining public confidence that the settlement process is addressing legitimate historical grievances and for increasing public understanding of the particular historical actions of the Crown which have impacted on the claimant group.

The Crown has to carefully consider whether it agrees with claimant arguments that particular Crown actions, or its failure to act, were wrong or unjust in Treaty terms. An insincere apology would lack good faith and would not contribute to a lasting reconciliation. As part of that process, the Crown will consider the implications of any apology it makes. While the claimant group releases the Crown from any further obligations, liabilities or duties in respect of their historical claims in a settlement, the apology may create precedents for other claims. ${ }^{34}$ Because the Crown is committed to resolving historical Treaty grievances the establishment of precedents sets up a framework to assist in the resolution of similar grievances for other claimant groups in future negotiations, but the Crown needs to assess in what situations such precedents might apply. An apology can also be considered to set standards for the future behaviour of the Crown. Sir Douglas Graham noted of the Crown's decision to apologise to Waikato-Tainui that 'there needed to be an understanding that in the future the 
relationship between Waikato and the Crown would be as envisaged by the Treaty - one of cooperation and good faith. ${ }^{, 35}$

An apology from the Crown can be powerful redress for claimant groups. For the first claimant groups to settle, the Crown's apology had high symbolism. Te Rünanga o Ngäi Tahu placed importance on the Crown's apology confirming the validity of the Ngäi Tahu claims, which had been borne by seven generations. They considered it part of a healing process, which would 'go a long way with our elders to atone for the past. It does not mean we forget the past, but it gives the Crown the opportunity to make amends, and for Ngäi Tahu and the Crown to move on with the healing process. It is also something that could only have been obtained through a negotiated settlement. No legal process could bring about such opportunity for reconciliation. To some Ngäi Tahu this is the most important part of the settlement. ${ }^{36}$

These sentiments have been echoed by Robert Joseph, who has written that the importance of the Crown's apology to Waikato-Tainui could not be overstated because it overcame the political and legal denial that had existed about their grievances. It was seen as an opportunity for both parties to move on with the healing process in a new relationship. ${ }^{37}$ Pat Heremaia, chief negotiator for the Ngäti Ruanui claims has also remarked that 'without the apology, the settlement would have been incomplete. ${ }^{38}$

Apology theorist Aaron Lazare has argued that some of the most successful apologies are the result of complex negotiations over a number of variables between the aggrieved and the offender. ${ }^{39}$ It is only through these negotiations that the offender can fully understand both the meaning of the grievance but also what is needed from the apology process. In Treaty settlements the apology negotiations give the claimant group and the Crown the opportunity to talk together about both the grievances and claimant group's expectations of the apology (this may include the form of the apology, what it will address, how it should be delivered and when). It is only when the two Treaty partners talking directly to each other and discuss their perceptions and interpretations of the history that has caused grievance that the groundwork for reconciliation can be laid. Such negotiations enable the Crown to apologise to the claimant group in a way that is meaningful to them.

While the Crown's willingness to listen to and discuss the grievances and ultimately apologise, is usually welcomed it can also be a challenging process for both parties. The offering of an apology is a clear statement that the Crown, in providing redress for past grievances, is seeking not just a legal settlement of the claims but also the more morally charged notion of some form of reconciliation between the parties. Claimant groups enter the settlement process because they want to settle the grievances of the past but may have some ambivalence through the process about the notion of reconciliation. They may question the sincerity of the Crown's intentions and whether the settlement negotiations and their outcome will be sufficient to address the sense of grievance and enable the beginning of a new relationship. This can be particularly evident at the start of 
negotiations when the past relationship between the parties may mean that trust levels are not high or where the Crown has not agreed with all of the Treaty breach allegations made by the claimant group.

In the majority of the settlements negotiated to date the claimants and the Crown have been through Waitangi Tribunal hearings on the claims before starting negotiations. Those hearings are an opportunity for claimants to fully press their claims against the Crown in a public forum as part of the process of telling their story to both the public and the Crown. Hearings are generally conducted in 'districts' and run along judicial processes of statements of claims and response by claimants and the Crown respectively. Once the 'issues' are established, the hearings focus on submissions by legal counsel and evidence from traditional and professional witnesses. The hearings therefore provide an opportunity for the Crown to test the claims advanced by claimants through crossexamination of those presenting historical evidence and through legal argument. The Crown has acknowledged Treaty breaches in some Tribunal hearing processes where the evidence, Treaty analysis and the claimant group who suffered prejudice as a result of Crown actions are all well established.

Before entering negotiations the Crown has to accept that its actions in relation to the claimant group have been in breach of the Treaty of Waitangi. If a Tribunal report is available when a claimant group seeks settlement negotiations the Crown will consider the Tribunal's findings and its supporting analysis. This may result in some shifting of the views the Crown expressed in its closing submissions to the Tribunal but the Crown may not agree with all of the findings of the Tribunal or their analysis. This may arise because the Crown has not presented evidence to the Tribunal on an issue, or does not agree with its analysis of the history or its Treaty responsibilities. In some cases claimant groups have also not agreed with all of the findings of the Tribunal. Even so, the prospect that the Crown may not agree with everything in their Tribunal report can be challenging for claimant groups. ${ }^{40}$ If claimant groups have forgone the Tribunal process or sought negotiation before a Tribunal report is available, the Crown will assess the available historical evidence for Treaty breach and agree to enter negotiations if it considers there is a well-founded grievance. ${ }^{41}$ In some recent cases groups who have forgone the Waitangi Tribunal process have also sought the opportunity to present their history and grievances directly to relevant Ministers of the Crown at hui. In either case, the Crown may not agree with every allegation of Treaty breach that the claimant group has made, but the negotiations present an opportunity for the parties to discuss those issues, listen to each others perspectives and try to find some resolution.

Every apology negotiation is unique. They tend to be shaped by the grievances of the claimant group, the research base for their claims, the extent to which there is agreement between the Crown and the claimant group's views of the ways in which the Crown breached the Treaty and the importance the claimant group places on the apology redress. The timing of the apology negotiations within the wider settlement negotiations varies. The apology is often 
negotiated concurrently with other parts of the settlement package but some claimant groups want to focus on the commercial and cultural elements of their settlement and are content to leave the apology negotiations until those parts of the settlement package have been substantially agreed. Others have chosen not to negotiate other parts of their redress package until the apology redress is significantly completed.

In most cases the parties establish an apology working group. The Crown is usually represented by officials with historical, policy and legal skills. Drafting is regularly reviewed by others who have general expertise in the issues involved. Claimant group negotiation teams vary, but are led by the mandated claimant negotiators. They may also draw on the expertise of kaumatua (elders), legal advisors, particular claimants and those who were involved in the research for the claim, including professional historians. The negotiators may also have drafting reviewed by appropriate people from within the claimant group from time to time. Negotiations are usually face to face, either in the claimant group's rohe (tribal area) or in Wellington, and can take many months of intensive meetings.

\section{HISTORICAL ACCOUNT}

Negotiations often begin with the parties discussing the drafting of the historical account, because the process of discussing the history and agreeing the text of the historical account will inform the eventual discussion of Treaty breaches and the Crown's apology. On the Crown's side the expectations for the historical account are that while both parties may wish to present alternative evidence or interpretations on particular aspects of the claim during the negotiations the objective will be to gain agreement on an account to be placed in the Deed of Settlement. The Crown considers it important that the historical account should reflect the available historical evidence so that it can withstand external scrutiny. The Crown also generally advocates for the language used in the historical account to be reasonably neutral and non-emotive and for any judgement of the events outlined in the account to be reserved for the section detailing the Crown's acknowledgements of Treaty breach, as this allows the reader to formulate their own assessment of the historical events and may facilitate public trust in the document.

Claimant expectations differ, but are generally that the historical account will reflect their grievances. The detailed negotiations will usually start with both parties agreeing on the issues that will be considered for inclusion in the historical account, whether the account will be broad and high level or more detailed and some assessment of there is sufficient research to inform the discussions. If a Tribunal report is available it will form the basis of the negotiations. There is also a great reliance on research produced for the Tribunal process and other research claimants or the Crown may hold, as well as a ranged of secondary literature and primary sources. Sometimes, particularly where a claimant group has come directly to negotiations rather than through the Tribunal process, or where they have claims that were not the focus of the Tribunal hearings, further 
supplementary research will be required on specific issues. Inevitably, the process of discussing the history and the issues that really matter to the claimant group may produce new historical questions or focus on new issues that might also require further investigation of primary sources.

The parties also agree on whether the claimant group or the Crown will do the first drafting and what that drafting should cover. If the parties agree a collaborative drafting approach, the drafting may proceed section by section. Otherwise there may be agreement to produce a full draft and then negotiate. Either way, both parties have to agree to the final text so once a draft has been started the parties will meet regularly to consider the drafting and negotiate agreed text.

The process of negotiating text which is considered by both parties to fairly recount the history and accurately address the grievances has some particular complexities. For a start, the parties are writing an historical account in a distinctive emotional, cultural, political and legal context. It will usually be the first time that the claimant group has had representatives of the Crown listen to them talk about their grievances and the impact on their people of past Crown actions in a face to face situation where the aim of both parties is to work out a mutually agreeable way of settling the grievances. ${ }^{42}$ Claimant negotiators also carry the responsibility of ensuring the grievances of their ancestors and their people are appropriately represented and are likely to have personal experience of the grievances (because 'historical' claims are defined as prior to 21 September 1992) or the impact of the grievances they are bringing to the table. There is more personal attachment to the history and to the results of the discussion than is usually the case in history writing. There are also, inevitably, methodological issues to be navigating in negotiating apology history. The desire to reflect the historical intentions of all the parties and the context for their actions (as far as can be deduced from the available evidence) can sometimes come into tension with the often 'presentist' lens through which both parties are assessing and judging that past, with the aim of resolving past grievances. ${ }^{43}$

The number of people contributing to and reviewing the drafting means that it is history writing by committee, and moreover, by negotiation. The discussion of the history will inevitably mean that both parties will learn more about each others perspectives. Both parties to the negotiations will also have particular issues to manage which may impact on the events included in the historical account or the wording chosen. Claimant negotiators, for example, may have to consider whether all the people they represent will be able to see their experience in the historical account or in the settlement more broadly and they may have to manage sensitivities about the naming of particular hapü or chiefs or individuals. The Crown may have to consider issues such as the naming of individual Crown officials and whether the Crown is taking a broadly consistent approach to similar issues across settlements.

The negotiations can also be informed by the cultural perspectives each party brings to the table. Both parties will also have to grapple with the usual issues of 
the uses, limitations and meanings of historical evidence. There are often questions about the extent to which the documentary evidence, whether written by Crown officials, settlers or Mäori, fully reflects the motives and understandings of the claimant group's ancestors. It can also be difficult to reconcile oral tradition and written sources, even sources written by Mäori. The parties may have to assess and try to agree what weight should be placed on oral evidence and what statements can be made when the grievances are significant but the available evidence is scanty, ambiguous or heavily debated. If oral evidence is the only source for a statement that will usually be made explicit in the historical account. In some cases information may only be within the realm of the claimant group's knowledge. For example, the parties may not consider it appropriate for the Crown to make a statement on the land area over which a claimant group exercised interests prior to contact with the Crown or to make statements about the impact of Crown actions on their spiritual connections with the land. Such statements may, therefore, be explicitly attributed to the claimant group.

The history produced by historical account negotiations is shaped by its purpose. The historical accounts agreed to date are short summary documents (usually between about 3-20 pages) shaped on a narrative of what happened. The content, the way it is expressed and what matters are given emphasis will reflect that its purpose is to inform an apology. Apology theorists have discussed how attempts by those who caused offence to explain the reasons for their actions can be seen by the aggrieved as trying to mitigate the impact of their actions. ${ }^{44}$ While both the Crown and claimant groups usually agree that it is important to include relevant context and outline the complexities of Crown and Mäori actions, there can be a perception that such context or explanation for events may mitigate the overall grievance. Conversely, the omission of context can draw criticism that the historical account does not fully reflect the complexities of the situation. ${ }^{45}$

While the aim of the negotiations is to get to an agreed historical account to be included in the Deed of Settlement specific Crown or iwi perspectives on the history can be reflected in the text. In addition, claimant groups have explored ways of recording their feelings about the impact of the Crown's actions on them in their historical account. Ngäti Ruanui and Ngäti Mutunga, for example, have negotiated the inclusion of a number of waiata (songs) in their historical account which record the feelings of their people about various events in their history. Ngäti Tuwharetoa (Bay of Plenty) have included statements in their historical account noting the impact of Crown actions on their connection to the land.

Both parties want the historical account to be able to withstand external scrutiny. In the last seven years the penultimate draft of a number of historical accounts have been reviewed by an 'eminent historian', who has not been involved in the negotiations. ${ }^{46}$ This review process can act as a check on the negotiated nature of the historical account, giving both parties the benefit of an external view of whether the text they have negotiated fairly represents the available evidence. The comments of the external historian are usually 
considered by both parties in the final negotiation and review of the historical account.

Producing narratives which focus on the grievances of the past has inevitably caused some debate over whether the settlement process is replacing one partial account of the past with another and over the quality of the history that is produced. ${ }^{47}$ Historical accounts are what Australians might call 'black armband history' because its aim is to outline the Crown actions which have caused grievance to the claimant group and breached the Treaty of Waitangi. They are negotiated for a political purpose of achieving reconciliation between the Crown and Mäori. They are not intended to be a full history of the claimant group or of the Crown and the claimant group's relationship over time. They may provide a starting point for people to start developing their own understanding of Crown's historical actions which have caused grievance to Mäori. The main role of the historical account is, however, to inform the Crown's acknowledgements of Treaty breach.

\section{CROWN ACKNOWLEDGementS}

The Crown's breach acknowledgements are where it makes an explicit judgement on the past. The assessment of Treaty breach involves a mix of legal, historical and political judgement. While the Crown may have made breach acknowledgements to a claimant group during Waitangi Tribunal hearings or at the start of the negotiations, the wording of the breach acknowledgements included in a claimant group's Deed of Settlement are usually developed after substantive discussion on the historical account has occurred. The Crown drafts its acknowledgements of Treaty breach but they are generally discussed extensively with the claimant group in negotiations. The Crown breaches acknowledged to date include breaches relating to war, the confiscation of land, human rights breaches including the execution of prisoners without trial in times of war, the impact of the native land laws, and the inadequate protection of land Mäori wished to retain. In some cases the Crown has acknowledged the sense of grievance that claimant groups have about Crown actions which the Crown has not accepted breached the Treaty.

In addition to making acknowledgments of its breaches of the Treaty, the Crown often also recognises the ongoing impacts its actions have had on the claimant group. The Ngäti Tuwharetoa (Bay of Plenty) acknowledgments explicitly recognise that the Crown's confiscation of their land had a 'damaging effect on the welfare, economy and development of Ngäti Tuwharetoa, deprived the iwi of access to its traditional natural resources and wähi tapu and contributed significantly to the subsequent dislocation and fragmentation of the iwi. ${ }^{48}$ There may also be recognition that wider New Zealand society has benefited from some of the events that have caused grievance to Mäori. In the Ngäti Awa settlement the Crown acknowledged that the land iwi had lost through the Crown confiscation and other means had 'made a significant contribution to the wealth 
and development of the nation, whilst Ngäti Awa have been alienated from and deprived of the benefits of those land and resources'. ${ }^{4}$

Once the acknowledgements are agreed, the apology is drafted by the Crown and presented to the claimant group for comment. The Crown generally tries to apologise to the claimant group in a way which will be meaningful for them. In some cases this has meant that the Crown has recognised the past and the ongoing impact of its breaches of the Treaty by apologising to the claimant community today, to their ancestors and to their descendants. The apology may use language that will have particular meaning for the claimant group. In the Ngäi Tahu apology the Crown recognised that it had 'failed to act towards Ngäi Tahu reasonably and with the utmost good faith in a manner consistent with the honour of the Crown. That failure is referred to in the Ngäi Tahu saying 'Te Hapa o Niu Tireni!' ('The unfulfilled promise of New Zealand'). ${ }^{, 50}$ The acknowledgements and apology have usually been expressed in the Mäori and English languages.

Claimant groups may make representations about the most appropriate way for the Crown to deliver the apology. Some consider its inclusion in the Deed of Settlement and legislation is sufficient. Other claimant groups, like Te Uri o Hau, have requested that once legislation has been passed and implementation of the settlement is underway representatives of the Crown deliver the apology directly to the claimant community.

To accept that its past actions have been wrong necessarily places the Crown in a morally humble position. As the offending party the Crown can only extend the apology and express that it is, with the settlement, seeking to atone for past wrongs and begin a process of healing. Reconciliation is a process that involves both parties and the response to the Crown's offer of an apology differs between groups according to their experiences. Willingness to settle the grievances will also depend on other elements of the settlement package. There is, however, evidence that the Crown's acknowledgement of and apology for past actions that were unjust may assist in making Treaty settlements a reconciliatory process.

In March 2003 representatives of the eastern Bay of Plenty tribe Ngäti Awa and the Crown met at Parliament Buildings in Wellington to sign a Deed of Settlement. It was the completion of a long journey. Ngäti Awa had actively sought redress for their grievances against the Crown, including the confiscation of approximately 245,000 acres of their land, since 1866. Professor Hirini Moko Mead, the chief negotiator for Ngäti Awa, outlined a number of the acknowledgements that the Crown had made about its confiscation of Ngäti Awa land in the Deed of Settlement to the gathering. He stated that in 'a final statement the Deed adds: "the Crown seeks to atone for these wrongs and begin the process of healing and looks forward to building a relationship of mutual trust and co-operation with Ngäti Awa".' In the spirit of these final statements of apology Ngäti Awa accepts the Crown's apology and on our part say that we forgive the Crown for what it did to us and we, too, want to begin the process of 
healing and we look forward to building a relationship of mutual trust, respect and co-operation. We will hold the Crown to that promise. ${ }^{.51}$

\section{ENDNOTES}

${ }^{1}$ Office of Treaty Settlements, Healing the Past, Building a Future - A Guide to Treaty of Waitangi Claims and Direct Negotiations with the Crown, Ka Tika ä Muri, Ka Tika ä Mua - He Tohutohu Whakamärama i ngä Whakatau Kerëme e pä ana ki Te Tiriti ö Waitangi me ngä Whakaritenga ki te Karauna, Office of Treaty Settlements, $1999, \mathrm{p} 3$.

${ }^{2}$ Northern Advocate, 26 July 2004.

${ }^{3}$ Hawkes Bay Today, 26 July 2004.

${ }^{4}$ Northern Advocate, 26 July 2004; Transcript of TV One 6pm News, 25 July 2004.

${ }^{5}$ For a list of major political apologies see http://reserve.mg2.org/apologies.htm. The New Zealand government has also made other apologies for historical injustices in recent years. These include an apology to those in the Chinese community who were required to pay a Poll Tax before entering New Zealand between the 1880 s and the 1930 s, and who suffered other discrimination imposed by statute. The apology was the beginning of a formal process of reconciliation and has been followed by the establishment of a community trust and a series of initiatives aimed at raising awareness of the early Chinese community in New Zealand and their history, language and culture (see the 'Chinese community consultation' section of www.ethnicaffairs.govt.nz and www.stevenyoung.co.nz/chinesevoice/misc/polltax2.htm ). In 2002 the New Zealand government also apologised to Samoa for the failings of New Zealand's early colonial administration in Samoa in relation to the 1918 influenza epidemic and the 1929 shooting of non-violent protestors by police.

${ }^{6}$ See for example, Roy L. Brooks (ed), When Sorry Isn't Enough: The Controversy Over Apologies and Reparations for Human Injustice, New York, 1999; Elazar Barkan, Guilt of Nations: Restitution and Negotiating Historical Injustices, New York, 2000; Emma Wethey, 'The Politics of Apology: Issues Arising from State Apologies to Indigenous Peoples for Historical Injustices in Australasia and North America', M. Phil in International Relations, University of Cambridge, 2002. The $20^{\text {th }}$ International Congress of Historical Sciences conference in Sydney in 2005 included a roundtable discussion on 'Injustice, Memory and Politics: Cases of Restitutions' with speakers on reparation debates relating to holocaust restitution, Japanese and German military sexual slavery, African American slavery and wars in a number of European countries.

${ }^{7}$ In addition to claims founded on a right arising from the Treaty of Waitangi and its principles, the modern Treaty settlement process also settles any claim under legislation or at common law or from a fiduciary duty arising from an act or omission before 21 September 1992 by or on behalf of the Crown or under legislation. Treaty settlements do not extinguish or limit any aboriginal title or customary rights that an iwi may have.

${ }^{8}$ The Treaty was drafted in English and then translated into Mäori. The Mäori text was then translated back into English and it is this text which became the 'official English text'. Most chiefs signed a Mäori language copy of the Treaty. An English text version of the Treaty was only taken to Waikato Heads and Manukau and was signed by 39 chiefs. Treaty of Waitangi Information Programme, The Story of the Treaty, Part 1 , State Services Commission, 2005, p13-14. Some of the differences in the Mäori and English texts of the Treaty are significant and have created ambiguity or different understandings about the meaning of the Treaty. Today, references to the Treaty in legislation seek to bridge the differences between the two texts by referring to Treaty 'principles'. The principles of the Treaty were described by Lord Woolf in the 1994 Broadcasting Assets case as 'the underlying mutual obligations and responsibilities the Treaty places on the parties. They reflect the intention of the Treaty as a whole and include, but are not confined to, the express terms of the Treaty.' Cited in The Treaty of Waitangi Information Programme, All About the Treaty, State Services Commission, 2005, p14.

${ }^{9}$ Office of Treaty Settlements, Ka Tika ä Muri, Ka Tika ä Mua - He Tohutohu Whakamärama i ngä Whakatau Kerëme e pä ana ki Te Tiriti ö Waitangi me ngä Whakaritenga ki te Karauna, Healing the Past, Building a Future - A Guide to Treaty of Waitangi Claims and Direct Negotiations with the Crown, , Office of Treaty Settlements, $2^{\text {nd }}$ ed, 2002, p12. This guide to settlements is available on the Office of Treaty Settlements website, www.ots.govt.nz.

${ }^{10}$ Action in the courts was not possible in most cases. A treaty such as the Treaty of Waitangi can only be enforced through the courts if it has been made part of New Zealand law through an Act of Parliament and this did not happen. Today, some statutes do incorporate references to Treaty principles, Office of Treaty Settlements, Ka Tika ä Muri, p19.

${ }^{11}$ http://www.ngaitahu.iwi.nz/About\%20Ngai\%20Tahu/The\%20Settlement/Claim\%20History\%20Overview. Accessed 30 April 2006.

${ }^{12}$ Office of Treaty Settlements, Ka Tika ä Muri, p19.

${ }^{13}$ The Tribunal is a permanent commission of inquiry and has up to 16 members who are appointed by the Governor-General on the recommendation of the Minister of Mäori Affairs in consultation with the Minister of Justice. The 16 members have included prominent business people, Mäori leaders, historians, exMinisters of the Crown, academics, ex-senior public servants and community leaders. Approximately half 
the members are Mäori and half are Pakeha. The Tribunal also has a chairperson, who is either the chief judge of the Mäori Land Court or a judge or retired judge of the High Court, and one of the judges of the Mäori Land Court also serves as the deputy chairperson.

${ }^{14}$ Office of Treaty Settlements, Ka Tika ä Muri, p19.

15 The Tribunal generally hears historical claims under a 'district inquiry' approach. This means that all of the historical claims relating to given area are grouped together for research and hearing.

${ }^{16}$ The Tribunal was later given the power, under particular circumstances, to order the Crown to 'resume' certain lands for use in a Treaty settlement. The two classes of land the Tribunal can order the Crown to use in Treaty settlements are Crown forest land that is subject to a Crown-forestry licence and

'memorialised lands'. The latter are lands which are owned or formerly owned by a State-Owned Enterprise or a tertiary institution or were former New Zealand Railways land, which have a statutory memorial or formal notation on their title that the Tribunal has the power to order the Crown to take back the property for use in a Treaty settlement, under certain circumstances, even if that land has since been transferred to a third party. Office of Treaty Settlements, Ka Tika ä Muri, p19-21 and p154-156.

${ }^{17}$ Office of Treaty Settlements, Ka Tika ä Muri, p21 and Douglas Graham, Trick or Treaty?, Institute of Policy Studies, Victoria University of Wellington, Wellington, 1997, p50.

${ }^{18}$ Office of Treaty Settlements, Crown Proposals for the Settlement of Treaty of Waitangi Claims:

Summary, Office of Treaty Settlements, Dept of Justice, Wellington, 1994, p5.

${ }_{19}$ Douglas Graham, op cit, p89.

${ }^{20}$ Douglas Graham, op cit, p51.

${ }^{21}$ Office of Treaty Settlements, Crown Proposals for the Settlement of Treaty of Waitangi Claims:

Summary, p7.

${ }^{22}$ Douglas Graham, op cit, p74. The Waikato-Tainui Deed of Settlement was signed in May 1995.

${ }^{23}$ Over 100 pre-consultation hui were also held throughout the country in order to inform Mäori communities of the detail of the Crown's proposals. Thirteen regional hui were planned to give Mäori an opportunity to respond to the formal presentation of the proposals by Ministers of the Crown, but two were cancelled at the behest of local Mäori, Report of Submissions: Crown Proposals for the Treaty of Waitangi Claims, Office of Treaty Settlements, Wellington, 1995, p2.

${ }^{24}$ Wira Gardiner, Return to Sender, What really happened at the fiscal envelope hui, Reed, Auckland, 1996.

${ }^{25}$ Office of Treaty Settlements, Crown Proposals for the Settlement of Treaty of Waitangi Claims: Summary, p5; Office of Treaty Settlements, Report of Submissions, Crown Proposals for the Treaty of Waitangi Claims, p 42 and p112.

${ }^{26}$ Office of Treaty Settlements, Report of Submissions, Crown Proposals for the Treaty of Waitangi Claims, p112.

${ }_{27}$ Douglas Graham, op cit, p49.

${ }^{28}$ Office of Treaty Settlements, Ka Tika ä Muri, p21.

${ }^{29}$ Historical settlements address grievances arising out of acts or omissions of the Crown up to 21

September 1992. That date was chosen as a cut-off date for 'historical' claims because that is the date when Cabinet agreed on the general principles for settling Treaty of Waitangi claims. Any claims which arise from Crown actions or omissions after that date are considered to be contemporary claims, Office of Treaty Settlements, Crown Proposals for the Settlement of Treaty of Waitangi Tribunal Claims, Summary, p11.

${ }^{30}$ Officials from other Government departments such as the Department of Conservation and Ministry of Fisheries are involved in negotiations as required. The Office of Treaty Settlements is also responsible for instructing the Crown Law Office which represents the Crown in Waitangi Tribunal hearings.

${ }^{31}$ Commercial properties included in settlements to date have included Crown exotic forest land, police stations, schools and properties within the Office of Treaty Settlements landbank (which holds properties, at the request of claimant groups, thathave been declared surplus to requirements by government departments). Claimant groups also sometimes negotiate a right of first refusal over surplus Crown property for a certain period of time. See Office of Treaty Settlements, Ka Tika ä Muri, pp87-95.

32 lbid p84. For a full outline of cultural redress see pp96-144.

33 Judge Layne Harvey, 'The Hearing and Settlement Process' in Waitangi Tribunal Conference 2004, New

Zealand Law Society, 2005 , p109.

${ }^{34}$ Wethey, op cit, p52.

${ }^{35}$ Douglas Graham, op cit p74.

${ }^{36} \mathrm{http}$ ://www.ngaitahu.iwi.nz. Accessed on 30 April 2006.

37 Robert Joseph, 'Denial, Acknowledgement and Peace Building Through Reconciliatory Justice', Te Mätähauariki Research Institute Working Paper, University of Waikato, August 2001, www.lianz.waikato.ac.nz/PAPERS/Rob/Denial.pdf, accessed on 30 April 2006.

${ }^{38}$ Wethey, op cit, p62.

${ }^{39}$ Aaron Lazare, On Apology, Oxford University Press, New York, 2004, p43.

${ }^{40}$ Greg White, 'Achieving Settlement', in Waitangi Tribunal Conference 2004, New Zealand Law Society, $2005, \mathrm{p} 121$.

${ }^{41}$ Because the Crown acknowledges that it has breached the Treaty in a number of ways it does not require detailed research into every Treaty breach, but it does seek evidence sufficient to show at a broad 
level the breaches of the Treaty which impacted on the claimant group. Office of Treaty Settlements, Ka Tika ä Muri, p41-42,

${ }^{42}$ Wethey, op cit, p56 and chapter ten.

${ }^{43}$ These tensions, often generated by the mix of legal, political and historical imperatives in the settlement process have been well canvassed in relation to the role of historians in the Waitangi Tribunal process. See, for example, Alan Ward, 'History and Historians before the Waitangi Tribunal, Some Reflections on the Ngai Tahu Claim' in Judith Binney (ed), The Shaping of History: Essays from the New Zealand Journal of History, Bridget Williams Books, Wellington, 2001, pp114-128 and Tipene O'Regan, 'Old Myths and New Politics, Some Contemporary Uses of Traditional History', Binney, op cit, pp19-23.

${ }^{44}$ Lazare, p120-127.

${ }^{45}$ For example, historian Bill Oliver has criticised the historical preamble to the Waikato Raupatu Claims Settlement Act 1995 for not providing enough context on the actions of Waikato-Tainui before the war which led to the raupatu, W. H. Oliver, 'Getting Facts on your Side: Waikato Raupatu Claims Settlement Act 1995', New Zealand Books, 1993, v5, no5, p15. In a minority opinion to the Waitangi Tribunal's report on the Kaipara claims, Tribunal member Michael Bassett argued that the Crown acknowledgements in the Te Uri of Hau settlement were sweeping and appeared to exclude Mäori from any responsibility for their ultimate landlessness, Waitangi Tribunal, The Kaipara Report, Legislation Direct, Wellington, 2006, pp. 359-362.

${ }^{46}$ The eminent historian review is generally undertaken by an academic chosen by the Crown and the claimant group, who has achieved professorial status and is well published.

${ }^{47}$ Most of the debate about the type of history the historical settlement process generates has been in relation to the history produced in Waitangi Tribunal reports. Some historians have critiqued the reports as being presentist, creating counter-factual history and using timeless principles to judge past acts and omissions by the Crown. There has also been academic recognition that the history the Tribunal produces is heavily shaped by its jurisdiction and the legal and political processes in which it operates. See, for example, M. P. L. Sorrenson, 'Towards a Radical Reinterpretation of New Zealand History: The Role of the Waitangi Tribunal', in I. H. Kawharu (ed), Waitangi: Mäori and Pakeha Perspectives on the Treaty of Waitangi, Oxford University Press, Auckland, 1989, pp158-178; W. H. Oliver, 'The Future Behind Us: The Waitangi Tribunal's Retrospective Utopia', in Andrew Sharp and Paul McHugh, Histories, Power and Loss: Uses and the Past - A New Zealand Commentary, Bridget Williams Books, Wellington, 2001, pp9-30; Giselle Byrnes, The Waitangi Tribunal and New Zealand History, Oxford University Press, Melbourne, 2004 and Michael Belgrave, Historical Frictions: Maori Claims and Reinvented Histories, Auckland University Press, 2005.

${ }^{48}$ Ngäti Tuwharetoa (Bay of Plenty) Claims Settlement Act 2005, Section 8, 2(b).

${ }^{49}$ Ngäti Awa Claims Settlement Act 2005, Section 8, 8(a).

${ }^{50}$ Ngäi Tahu Claims Settlement Act 1998, Section 6.

${ }^{51}$ Professor Hirini Moko Mead, Speech on the Occasion of the Signing of the Ngäti Awa Deed of Settlement with the Crown at Parliament Buildings, Wellington, 27 March 2003, http://www.ngatiawa.iwi.nz/documents/settlement/NADSS-27thMar.pdf, date accessed 30 April 2006. 